\title{
Fishers who rely on mangroves: Modelling and mapping the global intensity of mangrove-associated fisheries
}

\author{
Philine S.E. zu Ermgassen ${ }^{\text {a, }}$, Nibedita Mukherjee ${ }^{\mathrm{b}}$, Thomas A. Worthington ${ }^{\mathrm{b}}$,
}

Alejandro Acosta ${ }^{\mathrm{c}}$, Ana Rosa da Rocha Araujo ${ }^{\mathrm{d}}$, Christine M. Beitl ${ }^{\mathrm{e}}$, Gustavo A. Castellanos-Galindo ${ }^{\text {f,g }}$, Marília Cunha-Lignon ${ }^{\text {h }}$, Farid Dahdouh-Guebas ${ }^{\mathrm{i}, \mathrm{j}}$, Karen Diele $^{\mathrm{ac}}$, Cara L. Parrett ${ }^{\mathrm{k}}$, Patrick G. Dwyer ${ }^{1}$, Jonathan R. Gair ${ }^{\mathrm{m}}$, Andrew Frederick Johnson $^{\mathrm{n}, \mathrm{o}}$, Baraka Kuguru ${ }^{\mathrm{p}}$, Aaron Savio Lobo ${ }^{\mathrm{q}}$, Neil R. Loneragan ${ }^{\mathrm{r}}$, Kate Longley-Wood ${ }^{\text {, }}$, Jocemar Tomasino Mendonça ${ }^{\mathrm{t}}$, Jan-Olaf Meynecke ${ }^{\mathrm{u}}$, Roland Nathan Mandal ${ }^{\mathrm{v}}$, Cosmas Nzaka Munga ${ }^{\mathrm{w}, \mathrm{x}}$, Borja G. Reguero ${ }^{\mathrm{y}}$, Patrik Rönnbäck ${ }^{\mathrm{z}}$, Julia Thorley ${ }^{\text {aa }}$, Matthias Wolff ${ }^{\mathrm{g}}$, Mark Spalding ${ }^{\mathrm{b}, \mathrm{ab}}$

${ }^{a}$ Changing Oceans Group, School of Geosciences, Grant Institute, Kings Buildings, University of Edinburgh, EH9 3FE, UK

${ }^{\mathrm{b}}$ Department of Zoology, University of Cambridge, The David Attenborough Building, Pembroke Street, Cambridge, CB2 3QZ, United Kingdom

${ }^{\mathrm{c}}$ Florida Fish and Wildlife Conservation Commission, Fish and Wildlife Research Institute, 2796 Overseas Hwy Marathon FL, 33050, USA

${ }^{\mathrm{d}}$ Department of Fishery Engineering and Aquaculture, Federal University of Sergipe, Brazil

${ }^{\mathrm{e}}$ Department of Anthropology, University of Maine, 5773 S. Stevens Hall, 228A Orono, ME 044695773, USA

${ }^{\mathrm{f}}$ Smithsonian Tropical Research Institution (STRI), Panama / Leibniz Centre for Tropical Marine Research (ZMT), Germany

${ }^{g}$ Center for Tropical Marine Research (ZMT), Fahrenheitstrasse 6, 28358 Bremen, Germany

${ }^{\mathrm{h}}$ Department of Fishery Engineering, Universidade Estadual Paulista (UNESP), Campus Registro, 11900-00 Registro, SP, Brazil

${ }^{\mathrm{i}}$ Laboratory of Systems Ecology and Resource Management, Département de Biologie des Organismes, Université Libre de Bruxelles - ULB, Av. F.D. Roosevelt 50, CPi 264/1, 1050, Brussels, Belgium

${ }^{\mathrm{j}}$ Ecology \& Biodiversity, Laboratory of Plant Biology and Nature Management, Biology Department, Vrije Universiteit Brussel - VUB, Pleinlaan 2, VUB-APNA-WE, 1050, Brussels, Belgium

${ }^{\mathrm{k}}$ Department of Engineering, University of Cambridge, United Kingdom

${ }^{1}$ Coastal Systems, DPI Fisheries, 1243 Bruxner Hwy, Wollongbar New South Wales 2477, Australia

${ }^{\mathrm{m}}$ School of Mathematics, University of Edinburgh, King's Buildings, Peter Guthrie Tait Road, Edinburgh, EH9 3FD, UK

${ }^{\mathrm{n}}$ MarFishEco Fisheries Consultants, 3 F9 Antigua Street, Edinburgh, EH1 3NH, United Kingdom

${ }^{\circ}$ The Lyell Centre, Institute of Life and Earth Sciences, School of Energy, Geoscience, Infrastructure and Society, Heriot-Watt University, Edinburgh EH14 4AS, UK

p Tanzania Fisheries Research Institute P.O. Box 9750 Dar es Salaam, Tanzania

${ }^{\mathrm{q}}$ IUCN SSC Marine Conservation Committee, Sri Lanka

${ }^{\mathrm{r}}$ Environmental and Conservation Sciences, College of SHEE and Harry Butler Institute, Murdoch University, South Street, Murdoch, Western Australia 6150, Australia

s The Nature Conservancy, Arlington, VA, USA

${ }^{\mathrm{t}}$ Instituto de Pesca, Núcleo de Pesquisa do Litoral Sul, Av. Besnard, S/n. Cananeia, SP, CEP 11990-000, Brazil

${ }^{u}$ Griffith Centre for Coastal Management and Australian Rivers Institute, Griffith University, Gold Coast, Queensland 4222, Australia

${ }^{v}$ Agricultural and Fisheries Division, Center for Environmental and Geographic Information Services, Bangladesh

${ }^{\mathrm{w}}$ Department of Geography and Environmental Studies, School of Geography, University of the Witwatersrand, Johannesburg 2050, South Africa

${ }^{\mathrm{x}}$ Department of Environment and Health Sciences, Marine and Fisheries Program, Technical University of Mombasa, P.O. Box 90420 - 80100, Mombasa, Kenya

${ }^{\mathrm{y}}$ Institute of Marine Sciences. University of California, Santa Cruz. 115 McAllister Way, Santa Cruz, CA, USA

${ }^{\mathrm{z}}$ Natural Resources and Sustainable Development, Department of Earth Sciences, Uppsala University, Sweden

${ }^{\text {aa }}$ GIS Consultant, Penzance, Cornwall, UK

${ }^{\mathrm{ab}}$ The Nature Conservancy, Department of Physical, Earth and Environmental Sciences, University of Siena, Pian dei Mantellini, Siena 53100, Italy

${ }^{\text {ac }}$ School of Applied Sciences, Edinburgh Napier University, EH11 4BN, UK

\section{A B S T R A C T}

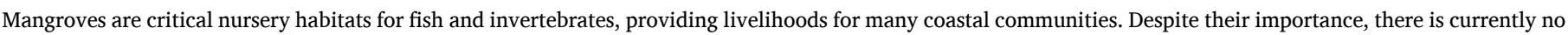

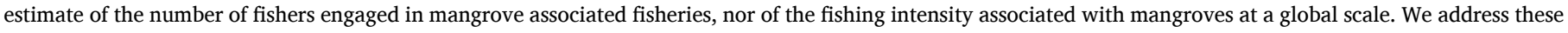

\footnotetext{
* Corresponding author.

E-mail address: philine.zuermgassen@cantab.net (P.S.E. zu Ermgassen).
} 


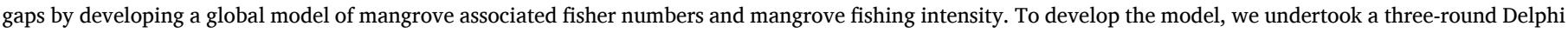

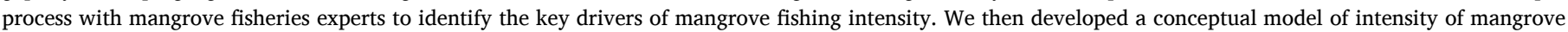

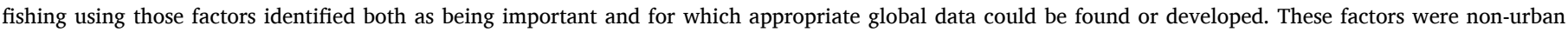

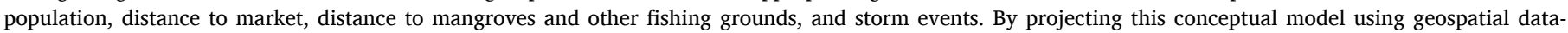

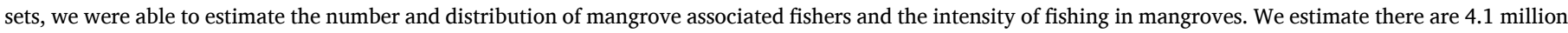

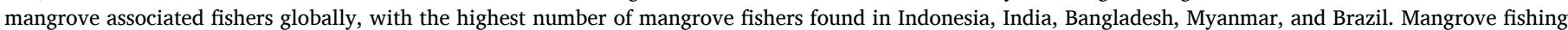
intensity was greatest throughout Asia, and to a lesser extent West and Central Africa, and Central and South America.

\section{Introduction}

Mangroves provide a suite of ecosystem functions and services such as coastal protection (Losada et al., 2018, Hochard et al., 2019), carbon sequestration (Donato et al., 2011), harvestable wood (Rasolofo, 1997), tourism (Spalding and Parrett, 2019) and fisheries (Carrasquilla-Henao and Juanes, 2017), yielding ecosystem service values of 25 US\$ trillion annually (including tidal marshes; Costanza et al., 2014). Although loss rates have declined since the late 20th century (losses of $0.16-0.39 \%$ annually between 2000 and 2012, Hamilton and Casey, 2016), mangroves are still being converted to other land-use types (Richards and Friess, 2016, Thomas et al., 2017). The decrease in mangrove loss is due in part to reduced deforestation rates, and in part to active restoration (Feller et al., 2017), with both facilitated by increased recognition of the vulnerability of mangroves and the enormous benefits they bring to people. Conservation planning, both with regards to protection and restoration, can be assisted by a clearer understanding of the spatial variability of the values derived from mangroves (Ferraro et al., 2015).

The contribution of mangroves to off-shore commercial fisheries is likely large, but remains widely debated (Blaber, 2007, Meynecke et al., 2007, Sheaves, 2017). By contrast, their contribution to near-shore fisheries, including bivalve, shrimp and crab fisheries, is well documented (Manson et al., 2005, Diele et al., 2010, Crow and Carney, 2013, Beitl, 2014). These near-shore fisheries include within-mangrove, and mangrove-adjacent fisheries that are typically subsistence, artisanal and small-scale commercially (Hutchison et al., 2015). The definition of small-scale fisheries varies from region to region (Smith and Basurto, 2019) and from country to country (Teh and Pauly, 2018). For the purpose of this study, we follow the definition of small-scale fishing from Teh and Sumaila (2011): "(i) primarily geared toward household consumption, sale at the local level, or export in the case of high value species; (ii) usually at low level (primary and secondary) of economic activity; (iii) for fulfilling cultural or ceremonial purposes; (iv) non-mechanized, or involve low technology and low capital investment; (v) undertaken by the fisher and/or family members only; (vi) conducted within inshore areas; and (vii) minimally managed".

The local importance of mangrove fisheries is well documented from diverse locations (e.g. India; Mexico; globally; Dahdouh-Guebas et al., 2006, Aburto-Oropeza et al., 2008, Carrasquilla-Henao and Juanes, 2017), and is likely to be particularly important in less economically developed countries (Aye et al., 2019). Indeed, a number of nations which are both highly reliant on fish as a source of protein and most vulnerable to micronutrient malnutrition (Golden et al., 2016), have significant mangrove extents (e.g. Cameroon, Guinea, Nigeria, Bangladesh, Indonesia) and large numbers of small-scale fishers (Teh and Sumaila, 2011). Unfortunately, despite these observations, and in the face of ongoing mangrove loss and the increasing risk of overfishing (Reis-Filho et al., 2018), there have been no large-scale efforts to quantify the intensity or number of small-scale mangrove associated fishers.

There is a growing understanding of the drivers of fisher behaviour and fishing intensity in tropical regions at local or species-specific scales (Muallil et al., 2013, Beitl, 2014, Duarte et al., 2014, Dacks et al., 2018). While there have been some efforts to map small-scale fisheries locally in the tropics (e.g. Leopold et al., 2014), efforts to understand the larger-scale spatial distribution of fishing intensity of small-scale fisheries is largely confined to temperate climates (Kavadas et al., 2015; Sini et al., 2019). The development of a comprehensive, quantitative understanding of the spatial variability in mangrove use by fishers could provide a critical tool for improving mangrove management and in securing or enhancing the livelihood benefits from their use. Models, maps and data from such work could greatly enhance both policy development and management interventions. Simultaneously, such information would provide a robust science base for communication and outreach regarding the importance of mangroves, generating better understanding at scales from local to global. It would also help stimulate sustained or improved conservation of mangrove ecosystem resources (Friess et al., 2020).

In this work we present the first global estimate of the number of small-scale mangrove associated fishers. In addition, we identified those mangrove areas where intensity of small-scale fishing is greatest. To develop our estimates, we used expert-driven elicitation to identify the key drivers of mangrove fishing intensity. These key drivers were then used to develop a conceptual model and map the spatial distribution of mangrove fishing intensity across 109 countries and territories.

\section{Methods}

Drivers of small-scale fisheries in mangrove habitats were identified through a three-round Delphi process with feedback provided at the end of each round. The expert-based, anonymous and iterative Delphi technique is well-suited to address complex issues and to address data gaps (Graefe and Armstrong, 2011; Mukherjee et al., 2015). This is pertinent given that mangroves are present in more than 100 countries (Spalding et al., 2010; Bunting et al., 2018) and vary in terms of geomorphic and sedimentary setting, and species assemblages. Given this diversity, it is to be expected that expert experiences across the global mangrove distribution may be varied. Delphi techniques are particularly powerful in gathering consensus compared to other qualitative techniques such as surveys, interviews or questionnaires (Mukherjee et al., 2018). The Delphi technique comprises two or more rounds of structured online surveys, each followed by an analysis of the responses and anonymous feedback to the participants (Mukherjee et al., 2015). Participants are offered the option to revise their initial estimates based on feedback from the group or defend their positions if their views are significantly different from the other respondents (Lemieux and Scott, 2011).

\subsection{Selecting participants}

Expert participants were selected via an open call for collaborators at the Mangrove \& Macrobenthos Meeting in St. Augustine, Florida (MMM4, 18th-22nd July 2016), and through an independent literature search in Web of Science undertaken in August 2016. To identify literature, we used the search terms "mangrove" and "fisheries" and the date range 1972-2016. All identified papers were examined to determine whether the research pertained to mangrove fisheries, as opposed to fish ecology. Studies using only national level datasets were also excluded, as we were seeking information on the finer-scale drivers of mangrove fisheries. All authors with one or more relevant publications, or identified through MMM4 were contacted by e-mail, provided with an overview of the project and the Delphi process. A total of 38 experts were 
identified and contacted and 17 experts participated in all rounds of the Delphi process. Participants were unaware of each other's identities during the Delphi process and all participants who completed the third round were invited as co-authors on this paper. The Delphi was undertaken between October 2016 and March 2017. Ethics clearance was obtained from the University of Cambridge before the survey was launched.

\subsection{The Delphi process}

In the first round of the Delphi, we used an open ended survey. Experts were asked to provide a ranked list of the twenty most important factors determining the volume of fish and invertebrate catch (Fig. 1a), excluding the ecological functions that determine fish and invertebrate density in mangroves (i.e. only factors determining fishing intensity). These responses were collated such that similar suggestions were grouped into a single factor, and factors that primarily influence the density of fish in mangrove areas were removed. Furthermore, factors relating to changing trends over time, such as climate change, were also excluded, as the scope of the work was to identify drivers of recent fishing intensity. A total of 46 factors were identified by the experts as affecting fishing intensity in mangrove fisheries (SOM1). These were shared with the experts and all were offered the opportunity to reflect and return comments on the list before the second round (Fig. 1a).

In the second round of the Delphi, experts were asked to identify which type of mangrove fisheries they were most familiar with, and were requested to score the factors in relation to that fishery type (Fig. 1d). The fisheries types were in-mangrove fisheries, near-shore artisanal/subsistence fisheries, near-shore commercial fisheries of mangrove associated species and off-shore commercial fisheries of mangrove associated species. Experts were asked whether the majority of factors of importance in determining mangrove fishing intensity in the fishery type they identified were also relevant in other fishery types, and if so, which fishery types. They were then asked to score the importance of each factor $(1=$ not important to $5=$ extremely important), as well as their certainty in their assessment $(1=$ no idea to $5=$ certain). We also solicited information regarding their opinions on the broader applicability of the factors they considered beyond their area of direct experience. The intention being to only include factors of global relevance to most mangrove fisheries species in the final model. Experts were therefore also asked to score the spatial scale of the relevance of the factors as either subnational, national, regional or universal, as well as the generality of the factors; i.e. whether the factors determine fishing intensity on all species, all species within a given type of fishery, or only to specific species or species groups.

After each round a summary report of responses was collated. The report outlined the frequency of each response for each question. Experts were asked to review all factors achieving consensus as being important (scored 4 or 5 with more than $70 \%$ of votes) and confirm that they agreed that these factors should be considered in the conceptual model. These factors were then not considered further in round 3 of the Delphi. Experts were also asked to confirm that they agreed with factors on which the consensus threshold (70\%) was passed for low importance (scored 1 or 2) being removed from further consideration (Fig. 1b). The consensus threshold on spatial scale and relevance across fishery types was set at $50 \%$, but only applied to the categories "universal" (i.e. globally relevant) and "universally relevant" across all fisheries species. Factors where a consensus was not reached were taken forward to round 3.

Following the second round, one additional factor, 'distance to port', a)
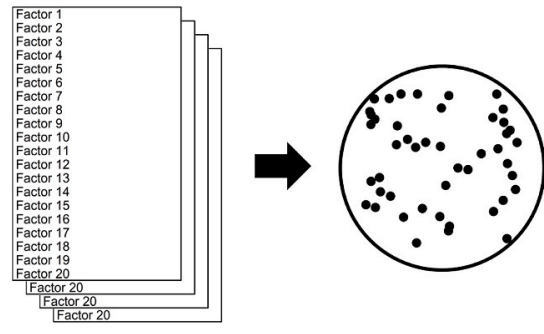

Delphi 1

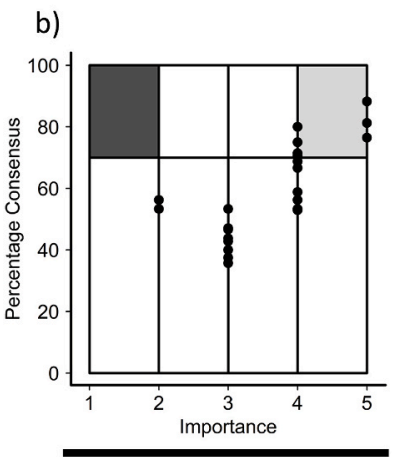

Delphi 2
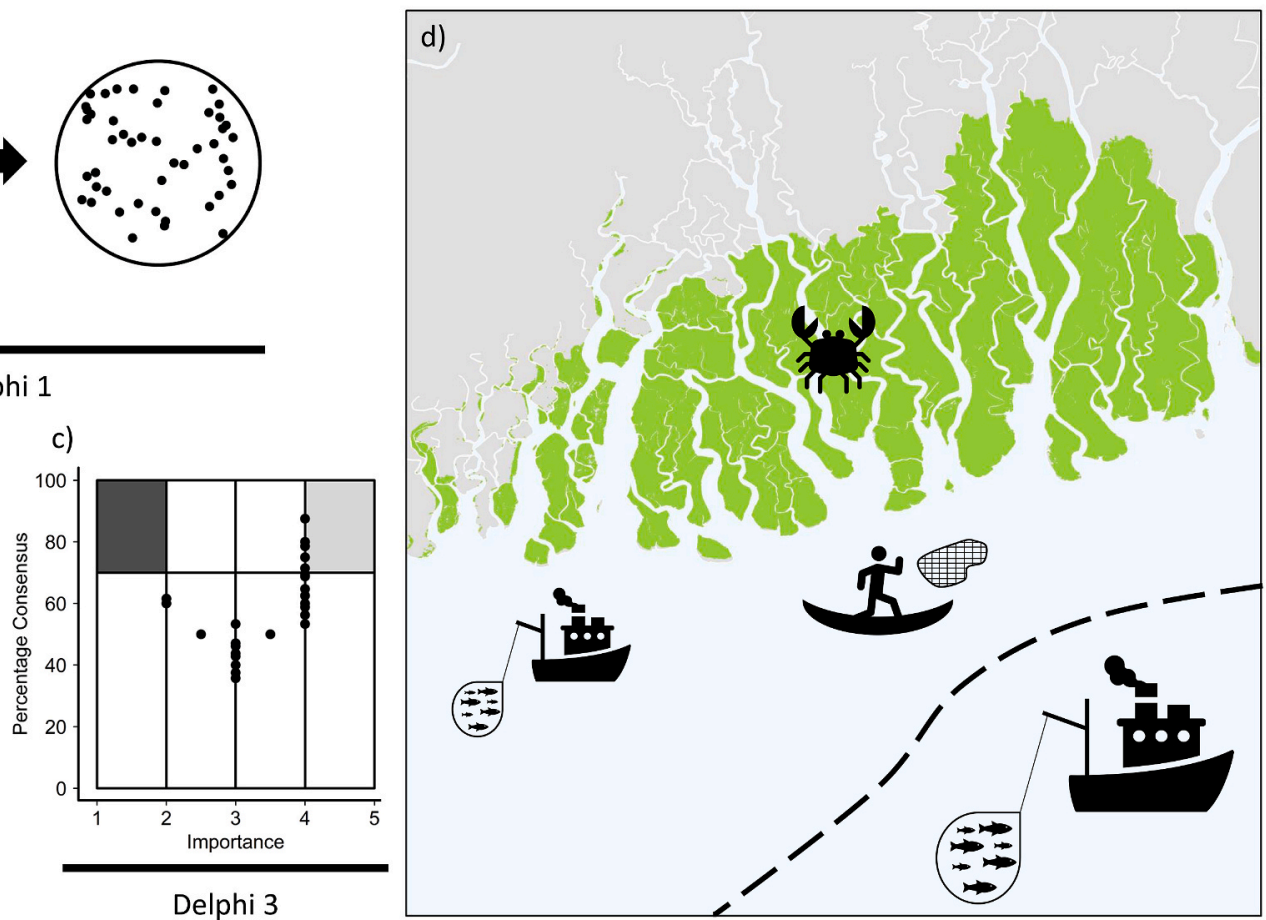

Fig. 1. The stages of the Delphi process a) Round 1, experts were asked to identify and rank the twenty most important factors determining the volume of fish and invertebrate catch which resulted in a pool of 46 factors, b) Round 2, experts were asked to rank the importance $(1=$ not important to $5=$ extremely important $)$ of the identified 46 factors. Those factors for which $>70 \%$ of respondents scored the factor 4 or 5 were retained for the model (light grey shaded area). Factors where $>70 \%$ of respondents scored the factor 1 or 2 were removed from consideration (dark grey shaded area). The figure shows the median importance versus the maximum percentage consensus for scores combined into three bins $(1-2,3,4-5)$, c) Round 3, experts were then asked to re-score the remaining factors, with factors retained for the model or removed based on the same criteria as in round 2 and d) experts were also asked to identify the type of fishery they were most familiar with. The fishery types were in-mangrove fisheries (crab icon), near-shore artisanal/subsistence fisheries (person throwing a net icon) or commercial fisheries (trawler icon) either near shore or off-shore (relative to dashed line). Mangrove extent (coloured green) from Bunting et al. (2018). (For interpretation of the references to colour in this figure legend, the reader is referred to the Web version of this article.) 
was introduced at the request of an expert. In the third round, experts were asked to re-score the remaining factors for the same questions (Fig. 1c). In addition, one factor "capture technique" which had met the thresholds for importance and consensus in round two was rescored as there was some confusion regarding the definition of "capture technique" relative to "fishing gear quality and type". Following consultation with the experts it was established that there was overlap between these categories, with capture technique defined as gear and method of deployment, whereas fishing gear quality and type related to gear type and maintenance. Further clarification on assessing the spatial scale at which factors were relevant was also provided; experts were asked to ensure that they were scoring the largest scale at which they believe the factor to be relevant. Where factors are universally relevant, their exact value may still vary spatially at a finer scale, e.g. population density varies along the coast, but may be important at larger scales than those over which it varies. A response of "regionally important" implied that the factor is important within a region, but would have no influence on mangrove fishing intensity in other regions. Factors which failed to reach the consensus threshold after round 3 were not taken forward for consideration in the conceptual model.

\subsection{Building the conceptual model of mangrove fishing intensity}

All the factors identified during the Delphi process that achieved consensus on the determinants of mangrove fishing intensity were reviewed. If these factors also achieved consensus as acting at a universal scale, they were considered for inclusion in the conceptual model of global mangrove fishing intensity (Table 1). Experts participating in the Delphi identified that their responses were only relevant to nearshore and in-mangrove fisheries. To translate this conceptual model into a map of mangrove fishing intensity, the availability of globally consistent geospatial data layers that could map and quantify each factor was evaluated. Where direct metrics for a factor were not available, the potential to develop proxy metrics was also considered. Of the initial 16 factors (Table 1), only four were identified as having data suitable for use in the development of a map of mangrove fishing intensity. These were: number of mangrove fishers, local non-urban population, accessibility to markets, and catchability as a result of weather. For these, mapping was performed at a resolution of $1 \mathrm{~km}^{2}$. National per capita fish consumption was not included despite being identified by the experts, as subsequent research identified that this statistic at a national level may not represent reliance on fish in coastal communities (Taylor et al.,

Table 1

Factors identified with consensus to be universally important in determining fishing intensity in mangroves, applicable globally, and across most fisheries species.

\begin{tabular}{ll}
\hline Theme & $\begin{array}{l}\text { Factor of high importance in determining fishing intensity in } \\
\text { mangroves }\end{array}$ \\
\hline Population & -Number of fishers (or vessels) \\
& -Local non-urban population \\
Culture & -National fish consumption per capita \\
& -Consumer demand (e.g. seasonality and cultural preference) \\
Markets & -Accessibility of market (e.g. presence of intermediaries and social \\
& networks to trade beyond local) \\
Individuals & -Price received by fisher for catch \\
& -Fisher experience (years) \\
& -Fishing gear quality and type \\
& -Capture technique \\
& -Degree of local resource dependence (alternative livelihood options) \\
Management & -Mangrove protected status \\
& -Existence of, and compliance to, fisheries management \\
& -Management (open access vs. community concession)/access to \\
& productive grounds) \\
& -Existence of some form of tenure \\
& -Catchability as a result of the animal's behaviour \\
& -Catchability as a result of natural environmental factors \\
& (tides, weather, disease)
\end{tabular}

2019). The Delphi process did not provide insight into the shape of the relationship between factors and fishing intensity and therefore conceptual models were developed following a thorough review of the literature.

It was assumed that small-scale fishers (SSF) are distributed proportionally with the local non-urban population (Stewart et al., 2010; Burke et al., 2011). The number of SSF was determined on a country-level from the available literature, principally Teh and Sumaila (2011) (SOM 2). However, as identified by the Delphi process, as well as other studies (e.g. Teh et al., 2013), there is not a single ratio of population to fishers that can be applied across a whole coastline as, for example, access to markets can drive up demand (Hamidu, 2012; FAO, 2014). There are, to our knowledge, no studies detailing the likely impact of markets on the number of artisanal and subsistence fishers. It is, however, well described that fish traders will purchase within a given range of a trading market, for example in the Philippines traders purchased their fish supply within 4-55 km of the trading market (Olalo, 2001). As access to ice or refrigeration is likely to be limited for many SFF throughout many of the mangrove areas we were seeking to characterise, we conservatively adopted a "market effect", by doubling the number of fishers per capita for all areas within $3 \mathrm{~h}$ travel time of cities with $>50,000$ people.

The number of SSF represent all coastal fishers, however, these individuals have access to a range of fishing opportunities across different habitats. Therefore, we partitioned fishers between the three major fishing habitats for which global datasets exist: shallow shelf areas, coral reefs and mangroves. In attributing a fisher to a particular habitat, it is important to first understand the accessibility of that habitat to the fisher. It is well established that travel time is a factor determining usage and that fishers spend more time fishing closer to their landing sites (Cabrera and Defeo, 2001; Gbigbi and Taiwo, 2014).

The exact relationship between distance and fishing effort is poorly characterised, but Chollett et al. (2014) represent a rare attempt to generalize a distance-fishing effort relationship for SSF. In order to assess whether the relationship given in Chollett et al. (2014) could be applied to mangrove SSF, we undertook a literature review and also examined the frequency distribution of reported distance from fishing ground to landing site in landings data for 2014 from Cananéia, Iguape, and Ilha Comprida, located in the Southern coast of São Paulo State in Brazil, collected by the Fishing Institute of São Paulo (Jocemar Tomasino Mendonça, unpublished data). This allowed us to assess the applicability of the model in Chollett et al. (2014) over a wide range of geographies (14 countries) and in Brazilian mangroves specifically (Jocemar Tomasino Mendonça, unpublished data; see SOM 3). We found the mathematical relationship described in Chollet et al. (2014) to be a reasonable reflection of the fishing effort we were seeking to model. We therefore applied equation (1) as presented in Chollett et al. (2014), normalised to a maximum distance of $45 \mathrm{~km}$, such that respectively $30.5 \%$ of fishers were deemed to fish $0-5 \mathrm{~km}, 45.5 \% 5-15 \mathrm{~km}, 19 \%$ $15-25 \mathrm{~km}$, and $5 \% 25-45 \mathrm{~km}$ from their location on the coast.

$E_{x}=e^{-\left(\frac{x}{18.13}\right)^{2}}$

We then determined the area of shallow shelf, coral reef and mangrove within $0-5 \mathrm{~km}, 5-15 \mathrm{~km}, 15-25 \mathrm{~km}$ and $25-45 \mathrm{~km}$ of each population grid and assigned "fishers" within each distance category to each habitat with the following ratios 10:10:1 coral reef:mangrove: shallow shelf. We were unable to find any empirical data to determine the relative time spent by fishers on shallow shelf as opposed to in mangroves or on coral reefs, however, it is well established that fishers deliberately target structured habitats (e.g. mangroves or coral reef) as fishing grounds (de la Torre-Castro et al., 2014) and therefore spend a disproportionate amount of time there. The practice of including but downweighting shallow shelf to model distribution of fishers is well established in determining coral reef fishing pressure (Burke et al., 
2011). At this stage, the estimated number of mangrove fishers could be calculated per country.

The final factor identified for the conceptual model of mangrove fishing intensity in the Delphi, was the impact of storms on frequency of fishing trips. In contrast to commercial vessels, artisanal fishing boats, typically of short boat lengths, are vulnerable to the impact of swell waves in open waters. For example, by one estimate, waves of $30-60 \%$ of a boat length can capsize the boat, and these ranges of wave heights usually occur in many areas globally for typical lengths of fishing boats (Tredup, 2011). To account for this, we applied a storm index that identifies the duration of stormy conditions along all mangrove areas. The storm index was derived from the Global Ocean Waves (GOW) database (Reguero et al., 2012). For the years 1948-2008, we calculated the duration of each storm that exceeded $2 \mathrm{~m}$ in significant wave height, and calculated the average percentage of time per year that conditions exceed this threshold. The final estimate of mangrove fishing intensity accounted for the number of fishers at each location, down-weighted by reduced fishing activity in proportion to the duration of storms limiting fishing activity. The number of fisher days per $\mathrm{km}^{2}$ of mangrove per year was determined by assuming fishers spend $60 \%$ of days fishing on average. Estimates in the literature for the number of days fished/year in coastal fisheries varies between 150 and 264 (Squires et al., 1998; Belhabib et al., 2013). Our estimate of 219 days per year is within that range of values. The response of fishers to storm events is poorly understood and likely varies with access to information and fishery type (Sainsbury et al., 2018). As fishers would be unable to fish during storms, especially in small artisanal fishing boats, we applied a correction for each day with $>2 \mathrm{~m}$ wave height as an initial estimate. These results provide the first global estimate of navigation conditions for artisanal fishing boats that account for storm wave conditions. To account for fishers altering their fishing practice or location in response to bad weather, as opposed to ceasing to fish (Allison and Ellis, 2001), we included storm days at a rate of 0.75 lost per storm day. The final resulting mangrove fishing intensity model therefore has the unit, fisher days $\mathrm{km}^{-2}$ year $^{-1}$. See SOM 4 for a detailed account of the application of the model in ArcGIS.

\section{Results}

\subsection{Delphi participants}

A total of 17 experts completed all rounds of the Delphi process to identify the most important drivers of mangrove fishing intensity. The participating experts represented experience of mangrove fisheries from 18 countries across all the major mangrove regions of the world (S. America, Central America, N. America, E. Africa, S.E. Asia, Australia), with the exception of West Africa. On average, participants had 13 years experience in both mangrove related and fisheries related research. Sixteen of the 17 participants identified fisheries catch or fisheries management as their primary area of expertise, with the remaining individual identifying primarily with fish habitat management. Half of the experts identified as being most familiar with in-mangrove fisheries, while a quarter of experts identified near-shore commercial and nearshore artisanal fisheries respectively. None of the experts were most familiar with off-shore commercial fisheries of mangrove associated species.

\subsection{Factors identified through the Delphi process}

Fourteen out of seventeen respondents thought that the majority of factors that were important in the fishery type they were most familiar with were also relevant across other fishery types. Applicability across type was particularly consistent for in-mangrove fisheries (93\% of the 14 respondents) and near-shore artisanal/subsistence fisheries (93\%), less so for near-shore commercial fisheries of mangrove associated species (79\%) and low for off-shore commercial fisheries of mangrove associated species (21\%). Given that none of the experts identified offshore commercial fisheries as the fishery type for which they submitted responses, the following results should be viewed as applying to near-shore and in-mangrove fisheries only.

Round 1 (R1) of the Delphi identified eleven factors for which there was consensus that the factor was important. No factors achieved consensus as being unimportant and all remaining factors were therefore taken forward to Round 2 (R2). There was a strong positive correlation between the median score for each factor and the maximum consensus percentage (consensus calculated for three bins, score of 1-2, score of 3, score of 4-5) $r=0.79, t_{44}=8.67, p<0.0001$ (Fig. 1b). Experts had certainty ( $\geq 50 \%$ consensus of scores of 4 or 5 ) in their scores for all factors. For six factors, consensus was reached that they were relevant at universal spatial scales, whereas there was no consensus on all remaining variables. There was consensus ( $\geq 50 \%)$ that 32 of the factors were generalisable across all species, with one factor (recreational fishing effort) thought to be specific to certain species or species groups only. There was no consensus on the generality for the remaining 13 factors.

Round 2 of the Delphi identified six (including a rescore of "capture technique" from R1) factors for which there was consensus that the factor was important. No factors were identified as being unimportant. Again, there was a strong positive correlation between the median score for each factor and the maximum consensus percentage (consensus calculated for three bins, score of $1-2$, score of 3, score of 4-5) $r=0.61$, $\mathrm{t}_{35}=4.59, \mathrm{p}<0.0001$ (Fig. 1b). There was certainty $(\geq 50 \%$ consensus of scores of 4 or 5) across the experts for 36 out of the 37 remaining factors, including the six that were identified as important. Most of the factors were relevant at regional or universal spatial scales $(n=25)$, whereas seven were deemed relevant at national or subnational scales, with three factors equally relevant across the two scales. There was consensus $(\geq 50 \%)$ that six of the remaining 14 factors ( 13 from R1 plus on new factor) were generalisable across all species, with five factors thought to be specific to certain species or species groups. There was no consensus of the generality for the remaining three factors.

Overall, there was consensus on sixteen factors as being important in determining fishing intensity in mangroves, and as being globally relevant. These factors could be grouped into six broader themes: population, culture, markets, individuals, management and catchability (Table 1).

\subsection{Global map of mangrove fishing intensity}

Our global model estimates the number of small scale mangrove fishers participating in in-mangrove, near-shore subsistence and artisanal and near-shore commercial fisheries is 4.1 million across 109 countries and territories. An average of $38 \%$ of SSF in the 109 countries and territories for which we derived estimates were mangrove fishers. The largest number of mangrove fishers were found in Indonesia, India, Bangladesh, Myanmar and Brazil (Fig. 2a, b, c; Table 2), while the countries with the greatest percentage of SSF fishing in mangroves were all in West and Central Africa; Guinea-Bissau (96\%), Guinea (95\%), Nigeria (89\%), Gabon (87\%), Sierra Leone (87\%), (Fig. 2d; see SOM 2 for results from all countries).

Mangrove fishing intensity showed high variability (Fig. 3), lower fishing intensity 0-100 fisher days $\mathrm{km}^{-2}$ year $^{-1}$ or 100-500 fisher days $\mathrm{km}^{-2}$ year $^{-1}$ was predicted for $29.4 \%$ and $25.4 \%$ of the global mangrove extent, respectively. Moderate mangrove fishing intensity (500-1500 and 1500-5000 fisher days $\mathrm{km}^{-2}$ year ${ }^{-1}$ ) was predicted across $21.1 \%$ and $16.5 \%$ of the global mangrove extent, respectively. The areas of highest mangrove fishing intensity (5000-10,000 and $>10,000$ fisher days $\mathrm{km}^{-2}$ year ${ }^{-1}$ ) covered $4.5 \%$ and $2.9 \%$ of the global mangrove extent, respectively. Regionally, mangrove fishing intensity was greatest throughout Asia, and to a lesser extent in West and Central Africa, and Central and South America (Table 3). At the national level in countries with $\geq 10 \mathrm{~km}^{2}$ of mangrove extent Ghana ( 8 thousand fisher days $\mathrm{km}^{-2}$ 

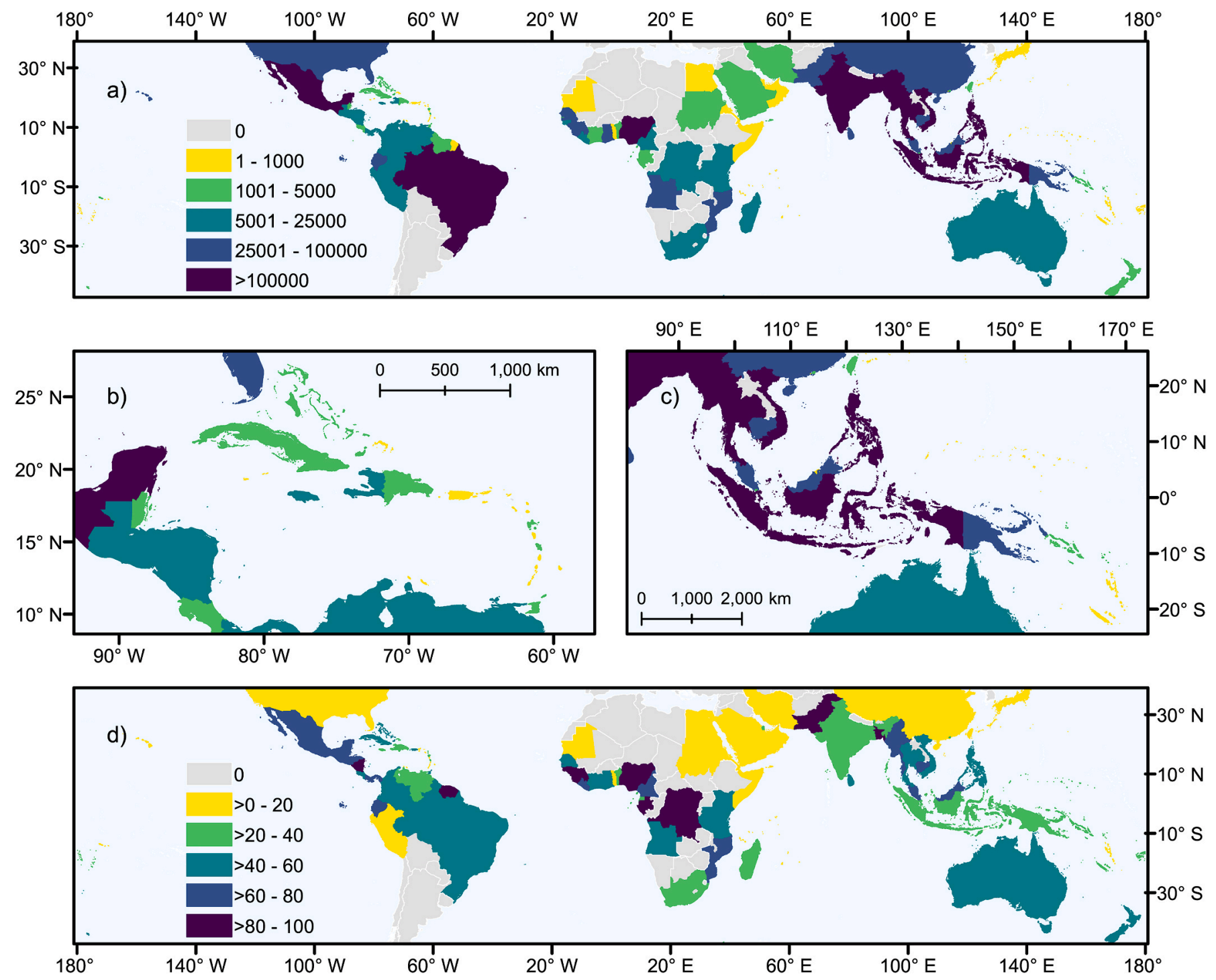

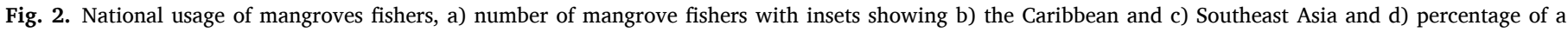
country's coastal small-scale fishers using mangrove habitats.

Table 2

Number of mangrove fishers (rounded to the nearest 1000), percentage of smallscale fishers fishing part or full time in or near mangroves, in the ten countries with the greatest number of mangrove fishers globally.

\begin{tabular}{lll}
\hline Country & Mangrove fishers & \% SFF who are mangrove fishers \\
\hline Indonesia & 893,000 & 39 \\
India & 570,000 & 38 \\
Bangladesh & 286,000 & 82 \\
Myanmar & 286,000 & 69 \\
Brazil & 278,000 & 53 \\
Vietnam & 240,000 & 44 \\
Mexico & 208,000 & 73 \\
Nigeria & 150,000 & 89 \\
Thailand & 127,000 & 55 \\
Philippines & 118,000 & 41 \\
\hline
\end{tabular}

year ${ }^{-1}$ ) India ( 5 thousand fisher days $\mathrm{km}^{-2}$ year $^{-1}$ ), Vietnam (5 thousand fisher days $\mathrm{km}^{-2}$ year ${ }^{-1}$ ), Sri Lanka and China (4 thousand fisher days $\mathrm{km}^{-2}$ year ${ }^{-1}$ ) had the highest predicted median mangrove fishing intensity.

Hotspots of fishing intensity also included the Cuanza River, Angola with a median of 40 thousand fisher days $\mathrm{km}^{-2}$ year $^{-1}$, the southern coastline of Madura Island, Indonesia (30 thousand fisher days $\mathrm{km}^{-2}$ year ${ }^{-1}$ ), the Citanduy River, Indonesia (25 thousand fisher days $\mathrm{km}^{-2}$ year ${ }^{-1}$ ), and the Kalubhar River, India (25 thousand fisher days $\mathrm{km}^{-2}$ year $^{-1}$ ), as well as multiple other areas along the coast of Indonesia and estuaries and deltas in India (Fig. 3a, $>10,000$ fisher days $\mathrm{km}^{-2} \mathrm{year}^{-1}$ ). Outside the mangroves of southern and southeast Asia, and west and central Africa, high fishing intensity was predicted for multiple mangrove patches around the coast of Brazil ( $>5000$ fisher days $\mathrm{km}^{-2}$ year $^{-1}$ ), and the Yingzai River, China (9 thousand fisher days $\mathrm{km}^{-2}$ year $^{-1}$ ).

\section{Discussion}

Mangrove forests provide many benefits - or ecosystem services - to coastal communities (Barbier et al., 2011; Brander et al., 2012; Himes-Cornell et al., 2018), including supporting fisheries which provide livelihoods and a source of protein (Carrasquilla-Henao and Juanes, 2017). Despite this obvious benefit there have been no large-scale efforts to quantify the number of fishers utilizing mangrove habitats or the spatial variability in mangrove fishing intensity. A greater understanding of the fisheries supported by mangroves could stimulate improved fisheries management and mangrove rehabilitation. Our analysis 

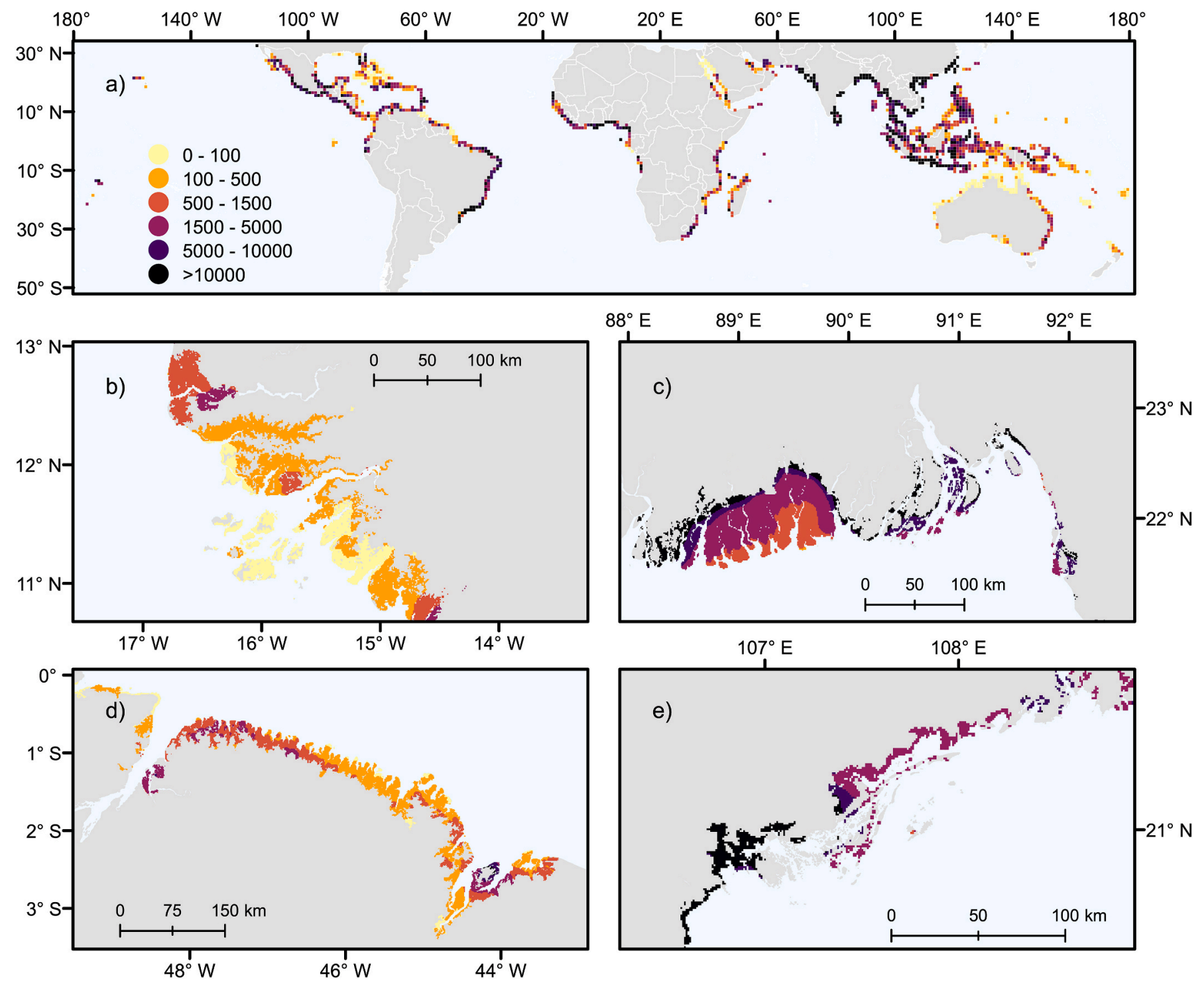

Fig. 3. Global map of small scale fishing intensity (fisher days $\mathrm{km}^{-2}$ year ${ }^{-1}$ ) within mangrove ecosystems, a) maximum fishing intensity within $1^{\circ}$ cells, high intensity areas (resolution $\mathrm{km}^{2}$ ) in b) Guinea-Bissau, c) the Sundarbans of Indian and Bangladesh and coast of Myanmar, d) deltaic coast of Brazil, and e) the coast of Vietnam and China.

Table 3

Median mangrove fishing intensity across mangrove regions identified in Spalding et al. (2010)

\begin{tabular}{lc}
\hline Region & $\begin{array}{c}\text { Median mangrove fishing intensity (fisher } \\
\text { days km } \text { year }^{-1} \text { ) }\end{array}$ \\
\hline East Asia & 4140 \\
South Asia & 3572 \\
West and Central Africa & 941 \\
South East Asia & 777 \\
South America & 398 \\
East and Southern Africa & 268 \\
North and Central America and the & 154 \\
$\quad$ Caribbean & \\
Middle East & 90 \\
Pacific Islands & 75 \\
Australia and New Zealand & $<1$ \\
\hline
\end{tabular}

presents a global estimate of mangrove fisher numbers and the spatial distribution of fishing intensity in mangroves, including highlighting the countries and locations where mangroves support large numbers of fishers or provide a high proportion of the small-scale fishery opportunities.

\subsection{Key drivers of mangrove fishing intensity}

The list of 16 factors identified by the experts as important globally in determining fishing intensity in mangroves provides a useful framework for downscaling the mapping approach, or when seeking to understand drivers of fishing intensity in mangrove areas on a smaller scale. Given the diversity of mangrove geomorphic settings (Thom, 1984; Woodroffe et al., 2016), accessibility and species richness (Spalding et al., 2010) around the world, as well as the diversity in human culture, it is striking that the expert panel were able to identify commonalities across mangrove areas. It should be noted that while we interpreted accessibility to markets as transport time within our own modelling effort, experts identified accessibility to markets as access to intermediaries. It is known that intermediaries visit remote sites less frequently Mapunda (1983), and at a global scale the experts agreed that areas closer to markets were more likely to have a greater number and diversity of intermediaries. Time to market was therefore deemed to be an appropriate proxy on a large scale. If downscaling the approach, or 
seeking to understand fishing intensity at a given location, more emphasis should be given to the presence of intermediaries and social networks.

Experts also placed a strong emphasis on management of mangrove areas. Overfishing in mangrove areas is a documented threat in many fisheries and locations (Hamidu, 2012; Reis-Filho et al., 2018). Conversely, there are also examples of successful sustainable resource management at a local level where communities are empowered and able to enforce management (Diele et al., 2010; Beitl, 2011). Such informal management structures are rarely reported and it is therefore difficult to collate such information at larger scales, whereas national or state-level management structures may be documented, but are often poorly enforced (Beitl, 2011; Schärer-Umpierre et al., 2014). As such, accounting for management at a large scale is currently challenging, and there is a pressing need to better document resource management practices across the whole spectrum of management options, as well as their effectiveness.

Through this work we have been able to define some of the broad commonalities that drive fishing intensity in mangroves globally. From this we have developed a model of mangrove fishing intensity, which represents a step forward from previous unitless models of global fishing intensity in mangroves. As such, this model represents the first attempt to develop a quantitative map of mangrove fishing intensity at a globalscale. However, a number of caveats should be considered when applying our results. Only a limited subset of the identified key drivers were mappable, and so the outputs are likely to be indicative, and only at broader scales. This is unsurprising given the key drivers were largely socio-economic in nature, variables which are challenging to produce from global scale remotely sensed data (Elvidge et al., 2009). Contributing experts did not have experience in West or Central Africa. While there is no reason to expect the underlying drivers, in particular the four we were able to include in the model, to differ with regards to their relative importance elsewhere in the world, the approach or downscaling of it should nevertheless be applied with caution in these regions. Furthermore, while we included the presence and abundance of shallow shelf and coral reef habitats in distributing fishing intensity in coastal waters, we were unable to include other targeted structured habitats, such as rocky reefs and seagrasses, which are similarly important fishing habitats (Zellmer et al., 2018; Jänes et al., 2020), due to a lack of information on their global distribution. This may result in over estimates of mangrove fishing intensity in areas where these habitats are abundant. The application of global datasets, such as the GOW dataset to account for the impact of storms also necessarily simplifies the impact on smaller scales. Fishers in areas where mangroves are sheltered in lagoons, or fishers who access the mangrove on foot in sheltered areas may not modify their behaviour in response to storm waves as we have modelled on a global scale. Finally, our numbers also only focus on near-shore fishers, excluding offshore fisheries for species such as prawns, which are enhanced by the presence of mangroves (Manson et al., 2005; Anneboina and Kavi Kumar, 2017; Jamizan and Chong, 2017). At the same time, the underlying model provides the opportunity for further development and refinement in future work.

\subsection{Estimate of mangrove associated fisher numbers}

We estimate that there are approximately 4.1 million mangrove associated fishers globally. Unsurprisingly, several of the countries with the largest number of mangrove fishers (Fig. 2), are also those countries that have the largest mangrove extents e.g. Indonesia, Brazil and Bangladesh. Despite this relationship, interesting anomalies are apparent. For instance, India is ranked tenth in terms of national mangrove area (Bunting et al., 2018), but Indian mangroves support the second largest number of small-scale fishers, with high fishing intensity predicted for many estuaries and deltas along the Indian coast (Fig. 3). Conversely, Australia despite its large mangrove estate was ranked 28th in number of mangrove fishers. Outside the southeast coastline,
Australia has very low coastal population densities and also a relatively wealthy population, both of which would likely contribute to these low numbers. Interestingly recreational fishing in mangroves is both popular and most likely represents a high value use in Australia, but is not covered by this model.

\subsection{Fishing intensity}

Fishing intensity on mangroves is highly spatially variable (Fig. 3). The nations and areas identified as having the highest fishing intensity were located in West and Central Africa, and South Asia and, South and Central America, where subsistence and artisanal fishing is a major livelihood, and it is well established that mangroves play a significant role in coastal livelihoods (Anneboina and Kavi Kumar, 2017; Hoque Mozumder et al., 2018; Sarathchandra et al., 2018; Aye et al., 2019). Although not considered in this model, fishing intensity may also vary temporally, given the seasonality of some species movements (Chavez et al., 2003; Niquen and Bouchon, 2004) and that seasonality shapes the decisions fishers make about what species to target and when to move on (Aswani, 1998; Daw et al., 2012; Pellowe and Leslie, 2017).

The model appears to work well at the large scale, with many countries where mangroves are recognised as important to fisheries having high mangrove fishing intensities (Table 2). There are, however, instances where the fact that we were able to include only four of the identified 16 drivers of fishing intensity in and near mangroves may have resulted in over or under estimates. For example, Cuba has a high modelled mangrove fishing intensity with $45 \%$ of SSF estimated to be mangrove fishers (SOM2), yet mangrove extent for the country is considerably less than then the estimated $>23,700 \mathrm{~km}^{2}$ of seagrass habitat present on the Cuban Shelf (Bunting et al., 2018; Martínez-Daranas and Suárez, 2018 ). In this case, the global model is likely to have resulted in an overestimate of fishing intensity in Cuba, as it was unable to account for seagrass habitat extent.

\section{Conclusion}

Small-scale fisheries are not only an important contributor to the national economies of many developing nations (e.g. Zeller et al., 2006; FAO, 2015), but are also a critical source of food and employment in many parts of the world where there are few alternative livelihoods (Teh and Sumaila, 2011; Teh et al., 2013). The role of mangroves in supporting small-scale fisheries is locally well evidenced (Dahdouh-Guebas et al., 2006; Aburto-Oropeza et al., 2008; Serafy et al., 2015; Carrasquilla-Henao et al., 2019), but efforts to understand the spatial distribution of mangrove fishing intensity at a larger scale have been hampered by a lack of consistency in available data (Hutchison et al., 2015). Understanding where mangroves are important for small-scale fishers is of policy relevance to several of the UN Sustainable Development Goals, including SDG 14 (Life Below Water), which includes the aim of promoting small-scale fishers' access to "productive resources, services and markets". Therefore effective management of mangrove areas with high fishing intensity should be prioritised.

Furthermore, local mangrove fisheries can support food security and help achieve SDG 1 (No Poverty) and SDG 2 (Zero Hunger). Five of the ten countries with the most mangrove fishers (Indonesia, Bangladesh, Nigeria, Thailand, Philippines) are also considered to be among those countries most reliant on fish as a source of protein and most vulnerable to malnutrition (Golden et al., 2016). The importance of mangroves for small-scale fishers in West Africa should also be noted (Fig. 2d). Many of the West and Central African nations were estimated to have more than $50 \%$ of small scale fishers engaged at least part time with fishing in or near mangroves, with five (Nigeria, Cameroon, The Gambia, Ivory Coast and Ghana) ranked among the most reliant on fish and vulnerable to malnutrition (Golden et al., 2016). Our results therefore further emphasise the importance of mangroves to people and to global food security. 
Our findings underline the intense levels of human use of mangroves for basic provisioning, particularly in areas where coastal populations and poverty are high, such as in West and Central Africa, and South and Southeast Asia. These findings give further strength to calls for mangrove conservation and restoration, and help to highlight countries and places where such interventions may be most critical.

\section{Ethics statement}

All authors were provided the option to leave the Delphi technique at any stage and participation was with informed consent. Prior ethics approval was obtained from the University of Cambridge ethics committee before starting the Delphi rounds. There is no conflict of interest to declare.

\section{Author contributions}

Conceptualization PSEzE, MS. Data curation: CD, PSEzE, KL-W, BR. Formal analysis NM, PSEzE, JT, KL-W, JRG, TW. Investigation: CMB, KD, PR, NL, J-OM, MW, PGD, AFJ, ARAA, AL, AC-L, JTM, GAC-G, AA, FD-G, BK, CM, RNM. Methodology PSEzE, NM, MS. Writing PSEzE, TW, MS. Review and editing: All authors.

\section{Declaration of competing interest}

The authors declare that they have no known competing financial interests or personal relationships that could have appeared to influence the work reported in this paper.

\section{Acknowledgements}

This work was funded as part of The Nature Conservancy's Mapping Ocean Wealth initiative and we are grateful for early support from the Lyda Hill Foundation. TW was supported by the International Climate Initiative (IKI) funded by the German Federal Ministry for the Environment, Nature Conservation and Nuclear Safety (BMU) on the basis of a decision adopted by the German Bundestag and an anonymous gift to The Nature Conservancy. KD acknowledges the Natural Environment Research Council Grant NE/S006990/1.

\section{Appendix A. Supplementary data}

Supplementary data to this article can be found online at https://doi. org/10.1016/j.ecss.2020.106975.

\section{SOM}

SOM 1 Global mangrove fisheries catch Delphi Round 1 summary.

SOM 2 Country level stats for small scale fishers, mangrove fisher number, $\%$ of SSF and fishing intensity.

SOM 3 Assessment of the relationship between fishing intensity and distance from landing site.

SOM 4 Mangrove fisher density mapping methodology.

\section{References}

Aburto-Oropeza, O., Ezcurra, E., Danemann, G., Valdez, V., Murray, J., Sala, E., 2008. Mangroves in the Gulf of California increase fishery yields. Proc. Natl. Acad. Sci. Unit. States Am. 105, 10456. https://doi.org/10.1073/pnas.0804601105.

Allison, E.H., Ellis, F., 2001. The livelihoods approach and management of small-scale fisheries. Mar. Pol. 25, 377-388. https://doi.org/10.1016/S0308-597X(01)00023-9.

Anneboina, L.R., Kavi Kumar, K.S., 2017. Economic analysis of mangrove and marine fishery linkages in India. Ecosyst. Serv. 24, 114-123. https://doi.org/10.1016/j. ecoser.2017.02.004.

Aswani, S., 1998. Patterns of marine harvest effort in southwestern New Georgia, Solomon Islands: resource management or optimal foraging? Ocean Coast Manag. 40, 207-235. https://doi.org/10.1016/S0964-5691(98)00047-7.
Aye, W.N., Wen, Y., Marin, K., Thapa, S., Tun, A.W., 2019. Contribution of mangrove forest to the livelihood of local communities in Ayeyarwaddy region, Myanmar. Forests 10, 414.

Barbier, E.B., Hacker, S.D., Kennedy, C., Koch, E.W., Stier, A.C., Silliman, B.R., 2011. The value of estuarine and coastal ecosystem services. Ecol. Monogr. 81, 169-193. https://doi.org/10.1890/10-1510.1.

Beitl, C.M., 2014. Navigating over space and time: fishing effort allocation and the development of customary norms in an open-access mangrove estuary in Ecuador. Hum. Ecol. 42, 395-411. https://doi.org/10.1007/s10745-014-9655-7.

Beitl, C.M., 2011. Cockles in custody: the role of common property arrangements in the ecological sustainability of mangrove fisheries on the Ecuadorian coast. Int. J. Commons 5, 485-512.

Belhabib, D., Mendy, A., Zeller, D., Pauly, D., 2013. Big fishing for small fishes: six decades of fisheries in the Gambia, "The smiling coast of Africa. Fish. Cent. Work. Pap. \#2013- 7, 20.

Blaber, S.J.M., 2007. Mangroves and fishes: issues of diversity, dependence, and dogma. Bull. Mar. Sci. 80, 457-472.

Brander, L.M., Wagtendonk, A.J., Hussain, S.S., McVittie, A., Verburg, P.H., de Groot, R. S., van der Ploeg, S., 2012. Ecosystem service values for mangroves in Southeast Asia: a meta-analysis and value transfer application. Ecosyst. Serv. 1, 62-69. https:// doi.org/10.1016/J.ECOSER.2012.06.003.

Bunting, P., Rosenqvist, A., Lucas, R., Rebelo, L.-M., Hilarides, L., Thomas, N., Hardy, A., Itoh, T., Shimada, M., Finlayson, C., 2018. The Global Mangrove Watch-a new 2010 global baseline of mangrove extent. Rem. Sens. 10, 1669. https://doi.org/ 10.3390/rs10101669.

Burke, L., Reytar, K., Spalding, M., Perry, A.L., 2011. Reefs at Risk Revisited. World Resources Institute, the Nature Conservancy, WorldFish Center, International Coral Reef Action Network. UNEP World Conservation Monitoring Centre and Global Coral Reef Monitoring Network, Washington, D.C.

Cabrera, J.L., Defeo, O., 2001. Daily bioeconomic analysis in a multispecific artisanal fishery in Yucatan, Mexico. Aquat. Living Resour 14, 19-28. https://doi.org/ 10.1016/S0990-7440(00)01094-9.

Carrasquilla-Henao, M., Ban, N., Rueda, M., Juanes, F., 2019. The mangrove-fishery relationship: a local ecological knowledge perspective. Mar. Pol. 108, 103656. https://doi.org/10.1016/j.marpol.2019.103656.

Carrasquilla-Henao, M., Juanes, F., 2017. Mangroves enhance local fisheries catches: a global meta-analysis. Fish Fish. 18, 79-93. https://doi.org/10.1111/faf.12168.

Chavez, F.P., Ryan, J., Lluch-Cota, S.E., Niquen, C.M., 2003. From Anchovies to Sardines and Back: Multidecadal Change in the Pacific Ocean. https://doi.org/10.1126/ science. 1075880

Chollett, I., Box, S., Mumby, P.J., 2014. Mapping the cost of an artisanal fishery. Proc. 66th Gulf Caribb. Fish. Inst. 66, 28-31.

Costanza, R., de Groot, R., Sutton, P., van der Ploeg, S., Anderson, S.J., Kubiszewski, I., Farber, S., Turner, R.K., 2014. Changes in the global value of ecosystem services. Global Environ. Change 26, 152-158. https://doi.org/10.1016/j. gloenvcha.2014.04.002.

Crow, B., Carney, J., 2013. Commercializing nature: mangrove conservation and female oyster collectors in the Gambia. Antipode 45, 275-293. https://doi.org/10.1111/ j.1467-8330.2012.01015.x.

Dacks, R., Ticktin, T., Jupiter, S.D., Friedlander, A., 2018. Drivers of fishing at the household scale in Fiji. Ecol. Soc. 23, 37. https://doi.org/10.5751/ES-09989230137.

Dahdouh-Guebas, F., Collin, S., Lo Seen, D., Ronnback, P., Depommier, D., Ravishankar, T., Koedam, N., 2006. Analysing ethnobotanical and fishery-related importance of mangroves of the East-Godavari Delta (Andhra Pradesh, India) for conservation and management purposes. J. Ethnobiol. Ethnomed. 2 https://doi.org/ 10.1186/1746-4269-2-24, 24-24.

Daw, T.M., Cinner, J.E., McClanahan, T.R., Brown, K., Stead, S.M., Graham, N.A.J., Maina, J., 2012. To fish or not to fish: factors at multiple scales affecting artisanal Fishers' readiness to exit a declining fishery. PLoS One 7, e31460. https://doi.org/ 10.1371/journal.pone.0031460.

de la Torre-Castro, M., Di Carlo, G., Jiddawi, N.S., 2014. Seagrass importance for a smallscale fishery in the tropics: the need for seascape management. Mar. Pollut. Bull. 83, 398-407. https://doi.org/10.1016/j.marpolbul.2014.03.034.

Diele, K., Araujo, A.R.R., Salzmann, U., 2010. Artisanal fishery of the mangrove crab Ucides cordatus (Ucididae) and first steps toward a successful co-management in Braganca, North Brazil. In: SaintPaul, U., Schneider, H. (Eds.), pp. 287-297.

Donato, D.C., Kauffman, J.B., Murdiyarso, D., Kurnianto, S., Stidham, M., Kanninen, M., 2011. Mangroves among the most carbon-rich forests in the tropics. Nat. Geosci. 4, 293-297. https://doi.org/10.1038/ngeo1123.

Duarte, L.F. de A., Duran, R.S., Mendonça, J.T., Pinheiro, M.A.A., 2014. Fishery of the Uça crab Ucides cordatus (Linnaeus, 1763) in a mangrove area in Cananéia, State of São Paulo, Brazil: fishery performance, exploitation patterns and factors affecting the catches. Braz. J. Oceanogr. 62, 187-199. https://doi.org/10.1590/S1679 87592014068906203.

Elvidge, C.D., Sutton, P.C., Ghosh, T., Tuttle, B.T., Baugh, K.E., Bhaduri, B., Bright, E 2009. A global poverty map derived from satellite data. Comput. Geosci. 35, $1652-1660$.

FAO, 2015. Voluntary Guidelines for Securing Sustainable Small-Scale Fisheries in the Context of Food Security and Poverty Eradication. Food and Agriculture Organization of the United Nations, Rome.

FAO, 2014. The State of World Fisheries and Aquaculture 2014. Food and Agriculture Organization of the United Nations, Rome.

Feller, I.C., Friess, D.A., Krauss, K.W., Lewis, R.R., 2017. The state of the world's mangroves in the 21st century under climate change. Hydrobiologia 803, 1-12. https://doi.org/10.1007/s10750-017-3331-z. 
Ferraro, P.J., Hanauer, M.M., Miteva, D.A., Nelson, J.L., Pattanayak, S.K., Nolte, C., Sims, K.R.E., 2015. Estimating the impacts of conservation on ecosystem services and poverty by integrating modeling and evaluation. Proc. Natl. Acad. Sci. Unit. States Am. 112, 7420. https://doi.org/10.1073/pnas.1406487112.

Friess, D.A., Yando, E.S., Abuchahla, G.M.O., Adams, J.B., Cannicci, S., Canty, S.W.J., Cavanaugh, K.C., Connolly, R.M., Cormier, N., Dahdouh-Guebas, F., Diele, K., Feller, I.C., Fratini, S., Jennerjahn, T.C., Lee, S.Y., Ogurcak, D.E., Ouyang, X., Rogers, K., Rowntree, J.K., Sharma, S., Sloey, T.M., Wee, A.K.S., 2020. Mangroves give cause for conservation optimism, for now. Curr. Biol. 30 (4), R153-R154. https://doi.org/10.1016/j.cub.2019.12.054.

Gbigbi, M.T., Taiwo, O., 2014. Technical efficiency and economic returns in artisanal fishery in the Niger-Delta, Nigeria. Int. J. Fish. Aquat. Stud. 2, 184-188.

Golden, C.D., Allison, E.H., Cheung, W.W., Dey, M.M., Halpern, B.S., McCauley, D.J., Smith, M., Vaitla, B., Zeller, D., Myers, S.S., 2016. Nutrition: fall in fish catch threatens human health. Nature 534, 317-320. https://doi.org/10.1038/534317a.

Graefe, A., Armstrong, J.S., 2011. Comparing face-to-face meetings, nominal groups, Delphi and prediction markets on an estimation task. Int. J. Forecast. 27, 183-195. https://doi.org/10.1016/j.ijforecast.2010.05.004.

Hamidu, U.M., 2012. Assessment of the Marine Artisanal Fisheries in Tanzania Mainland. University of Iceland. MSci Thesis, p. 51pp.

Hamilton, S.E., Casey, D., 2016. Creation of a high spatio-temporal resolution global database of continuous mangrove forest cover for the 21st century (CGMFC-21). Global Ecol. Biogeogr. 25, 729-738. https://doi.org/10.1111/geb.12449.

Himes-Cornell, A., Pendleton, L., Atiyah, P., 2018. Valuing ecosystem services from blue forests: a systematic review of the valuation of salt marshes, sea grass beds and mangrove forests. Ecosyst. Serv. 30, 36-48. https://doi.org/10.1016/J. ECOSER.2018.01.006.

Hochard, J.P., Hamilton, S., Barbier, E.B., 2019. Mangroves shelter coastal economic activity from cyclones. Proc. Natl. Acad. Sci. U.S.A. 116, 12232-12237. https://doi org $/ 10.1073 /$ pnas.1820067116.

Hoque Mozumder, M.M., Shamsuzzaman, M.M., Rashed-Un-Nabi, M., Karim, E., 2018. Social-ecological dynamics of the small scale fisheries in Sundarban Mangrove Forest, Bangladesh. Aquac. Fish. 3, 38-49. https://doi.org/10.1016/j. aaf.2017.12.002.

Hutchison, J., Philipp, D.P., Claussen, J.E., Aburto-Oropeza, O., Carrasquilla-Henao, M. Castellanos-Galindo, G.A., Costa, M.T., Daneshgar, P.D., Hartmann, H.J., Juanes, F., Khan, M.N., Knowles, L., Knudsen, E., Lee, S.Y., Murchie, K.J., Tiedemann, J., zu Ermgassen, P., Spalding, M., 2015. Building an expert-judgment-based model of mangrove fisheries. Am. Fish. Soc. Symp. 83, 17-42.

Hutchison, J., zu Ermgassen, P.S.E., Spalding, M., 2015. The current state of knowledge on mangrove fishery values. Trans. Am. Fish. Soc. 83, 3-15.

Jamizan, A.R., Chong, V.C., 2017. Demersal fish and shrimp abundance in relation to mangrove hydromorpological metrics. Sains Malays. 46, 9-19. https://doi.org/ 10.17576/jsm-2017-4601-02.

Jänes, H., Macreadie, P.I., zu Ermgassen, P.S.E., Gair, J.R., Treby, S., Reeves, S., Nicholson, E., Ierodiaconou, D., Carnell, P., 2020. Quantifying fisheries enhancement from coastal vegetated ecosystems. Ecosystem Services 43, 101105.

Kavadas, S., Maina, I., Damalas, D., Dokos, I., Pantazi, M., Vassilopoulou, V., 2015. Multi-Criteria Decision Analysis as a tool to extract fishing footprints and estimate fishing pressure: application to small scale coastal fisheries and implications for management in the context of the Maritime Spatial Planning Directive. Mediterr. Mar. Sci. 16, 294-304. https://doi.org/10.12681/mms.1087.

Lemieux, C.J., Scott, D.J., 2011. Changing climate, challenging choices: identifying and evaluating climate change adaptation options for protected areas management in Ontario, Canada. Environ. Manag. 48, 675-690. https://doi.org/10.1007/s00267011-9700-x.

Leopold, M., Guillemot, N., Rocklin, D., Chen, C., 2014. A framework for mapping smallscale coastal fisheries using Fishers' knowledge. ICES J. Mar. Sci. 71, 1781-1792. https://doi.org/10.1093/icesjms/fst204.

Losada, I.J., Menéndez, P., Espejo, A., Torres, S., Díaz-Simal, P., Abad, S., Beck, M.W., Narayan, S., Trespalacios, D., Pfiegner, K., Mucke, P., Kirch, L., 2018. The Global Value of Mangroves for Risk Reduction. The Nature Conservancy, Berlin. Technical Report.

Manson, F.J., Loneragan, N.R., Harch, B.D., Skilleter, G.A., Williams, L., 2005. A broadscale analysis of links between coastal fisheries production and mangrove extent: case-study for northeastern Australia. Fish. Res. 74, 69-85. https://doi.org/ 10.1016/j.fishres.2005.04.001.

Mapunda, X.E., 1983. Fisheries economics in the context of the artisanal fisheries of the marine sector. SWIOP Document OISO. RAF/79. /065/WP/7/83, p. 6.

Martínez-Daranas, B, Suárez, AM, 2018. An overview of Cuban seagrasses. Bull. Mar. Sci. 94, 269-282. https://doi.org/10.5343/bms.2017.1014.

Meynecke, J.-O., Lee, S.Y., Duke, N.C., Warnken, J., 2007. Relationships between estuarine habitats and coastal fisheries in Queensland, Australia. Bull. Mar. Sci. 80, 773-793.

Muallil, R.N., Cleland, D., Aliño, P.M., 2013. Socioeconomic factors associated with fishing pressure in small-scale fisheries along the West Philippine Sea biogeographic region. Ocean Coast Manag. 82, 27-33. https://doi.org/10.1016/j. ocecoaman.2013.04.013.

Mukherjee, N., Hugé, J., Sutherland, W.J., McNeill, J., Van Opstal, M., DahdouhGuebas, F., Koedam, N., 2015. The Delphi technique in ecology and biologica conservation: applications and guidelines. Methods Ecol. Evol. 6, 1097-1109. https://doi.org/10.1111/2041-210X.12387.

Mukherjee, N., Zabala, A., Hugé, J., Nyumba, T.O., Adem Esmail, B., Sutherland, W.J. 2018. Comparison of techniques for eliciting views and judgements in decisionmaking. Methods Ecol. Evol. 9, 54-63. https://doi.org/10.1111/2041-210X.12940.
Ñiquen, M., Bouchon, M., 2004. Impact of El Niño events on pelagic fisheries in Peruvian waters. Deep-Sea Research Part II: Topical Studies in Oceanography, pp. 563-574. https://doi.org/10.1016/j.dsr2.2004.03.001.

Olalo, C., 2001. Production, accessibility and consumption patterns of aquaculture products in the Philippines. In: Production, Accessibility and Consumption Patterns of Aquaculture Products in Asia: A Cross-Country Comparison, vol. 973. FAO Fisheries Circular, Rome.

Pellowe, K.E., Leslie, H.M., 2017. Seasonal variability shapes resilience of small-scale fisheries in Baja California Sur, Mexico. PLoS One 12, e0182200. https://doi.org/ 10.1371/journal.pone.0182200.

Rasolofo, M.V., 1997. Use of mangroves by traditional fishermen in Madagascar. Mangroves Salt Marshes 1, 243-253. https://doi.org/10.1023/a:1009923022474.

Reguero, B.G., Menéndez, M., Méndez, F.J., Mínguez, R., Losada, I.J., 2012. A Global Ocean Wave (GOW) calibrated reanalysis from 1948 onwards. Coast. Eng. 65 38-55. https://doi.org/10.1016/j.coastaleng.2012.03.003.

Reis-Filho, J.A., Harvey, E.S., Giarrizzo, T., 2018. Impacts of small-scale fisheries on mangrove fish assemblages. ICES J. Mar. Sci. 76, 153-164. https://doi.org/10.1093/ icesjms/fsy110.

Richards, D.R., Friess, D.A., 2016. Rates and drivers of mangrove deforestation in Southeast Asia, 2000-2012. Proc. Natl. Acad. Sci. Unit. States Am. 113, 344-349. https://doi.org/10.1073/pnas.1510272113.

Sainsbury, N.C., Genner, M.J., Saville, G.R., Pinnegar, J.K., O’Neill, C.K., Simpson, S.D., Turner, R.A., 2018. Changing storminess and global capture fisheries. Nat. Clim. Change 8, 655-659. https://doi.org/10.1038/s41558-018-0206-x.

Sarathchandra, C., Kambach, S., Ariyarathna, S.C., Xu, J., Harrison, R.D. Wickramasinghe, S., 2018. Significance of mangrove biodiversity conservation in fishery production and living conditions of coastal communities in Sri Lanka. Diversity 10, 20. https://doi.org/10.3390/d10020020.

Schärer-Umpierre, M.T., Mateos-Molina, D., Appeldoorn, R., Bejarano, I., HernándezDelgado, E.A., Nemeth, R.S., Nemeth, M.I., Valdés-Pizzini, M., Smith, T.B., 2014. Marine managed areas and associated fisheries in the US Caribbean. Adv. Mar. Biol. 69, 129-152. https://doi.org/10.1016/B978-0-12-800214-8.00004-9.

Serafy, J.E., Shideler, G.S., Araújo, R.J., Nagelkerken, I., 2015. Mangroves enhance reef fish abundance at the Caribbean regional scale. PLoS One 10, e0142022. https://doi. org/10.1371/journal.pone.0142022.

Sheaves, M., 2017. How many fish use mangroves? The $75 \%$ rule an ill-defined and poorly validated concept. Fish Fish. 18, 778-789. https://doi.org/10.1111 faf.12213.

Sini, M., Vatikiotis, K., Thanopoulou, Z., Katsoupis, C., Maina, I., Kavadas, S., Karachle, P.K., Katsanevakis, S., 2019. Small-scale coastal fishing shapes the structure of shallow rocky reef fish in the Aegean Sea. Front. Mar. Sci. 6 https://doi. org/10.3389/fmars.2019.00599.

Smith, H., Basurto, X., 2019. Defining small-scale fisheries and examining the role of science in shaping perceptions of who and what counts: a systematic review. Front. Mar. Sci. 6 https://doi.org/10.3389/fmars.2019.00236.

Spalding, M., Parrett, C.L., 2019. Global patterns in mangrove recreation and tourism. Mar. Pol. 110, 103540. https://doi.org/10.1016/j.marpol.2019.103540.

Spalding, M.D., Kainumu, M., Collins, L., 2010. World Atlas of Mangroves. Earthscan, London, UK; Washington, DC.

Squires, D., Grafton, R.Q., Ferdous Alam, M., Omar, I.H., 1998. Where the land meets the sea: integrated sustainable fisheries development and artisanal fishing. Univ. Calif. San Diego Dep. Econ. Discuss. Pap, 98-26.

Stewart, K.R., Lewison, R.L., Dunn, D.C., Bjorkland, R.H., Kelez, S., Halpin, P.N., Crowder, L.B., 2010. Characterizing fishing effort and spatial extent of coastal fisheries. PloS One 5, e14451. https://doi.org/10.1371/journal.pone.0014451.

Taylor, S.F.W., Roberts, M.J., Milligan, B., Ncwadi, R., 2019. Measurement and implications of marine food security in the Western Indian Ocean: an impending crisis? Food Secur 11, 1395-1415. https://doi.org/10.1007/s12571-019-00971-6.

Teh, L.C.L., Pauly, D., 2018. Who brings in the fish? The relative contribution of smallscale and industrial fisheries to food security in Southeast Asia. Front. Mar. Sci. 5 https://doi.org/10.3389/fmars.2018.00044.

Teh, L.C.L., Sumaila, U.R., 2011. Contribution of marine fisheries to worldwide employment. Fish Fish. 14, 77-88. https://doi.org/10.1111/j.1467 2979.2011.00450.x.

Teh, L.S.L., Teh, L.C.L., Sumaila, U.R., 2013. A global estimate of the number of coral reef Fishers. PLoS One 8, e65397. https://doi.org/10.1371/journal.pone.0065397.

Thom, B.G., 1984. Coastal landforms and geomorphic processes. In: Snedaker, S.C., Snedaker, J.G. (Eds.), The Mangrove Ecosystem: Research Methods. UNESCO, Paris, France, pp. 18-35.

Thomas, N., Lucas, R., Bunting, P., Hardy, A., Rosenqvist, A., Simard, M., 2017. Distribution and drivers of global mangrove forest change, 1996-2010. PLoS One 12, e0179302. https://doi.org/10.1371/journal.pone.0179302.

Tredup, S., 2011. Dangerous waves and your boat. Ocean Navigator. http://www.ocea nnavigator.com/Ocean-Voyager-2011/Dangerous-waves-and-your-boat/. (Accessed August 2018).

Woodroffe, C.D., Rogers, K., McKee, K.L., Lovelock, C.E., Mendelssohn, I.A., Saintilan, N., 2016. Mangrove sedimentation and response to relative sea-level rise. Annu. Rev. Mar. Sci. 8, 243-266. https://doi.org/10.1146/annurev-marine-122414-034025.

Zeller, D., Booth, S., Pauly, D., 2006. Fisheries contributions to the gross domestic product: underestimating small-scale fisheries in the Pacific. Mar. Resour. Econ. 21, 355-374. https://doi.org/10.1086/mre.21.4.42629521.

Zellmer, A.J., Claisse, J.T., Williams, C.M., Pondella Ii, D.J., 2018. Long-term, spatial marine harvest intensity as an indicator of human impact on shallow rocky reef ecosystems. Mar. Ecol. 39, e12463. 